\title{
The Effect of Excipients on the Permeability of BCS Class III Compounds and Implications for Biowaivers
}

\author{
Alan Parr ' Ismael J. Hidalgo ${ }^{2} \cdot$ Chris Bode $^{2}$ (D) - William Brown ${ }^{3} \cdot$ Mehran Yazdanian $^{4}$ - Mario A. Gonzalez ${ }^{5} \cdot$ Kazuko Sagawa $^{6}$. \\ Kevin Miller ${ }^{\prime} \cdot$ Wenlei Jiang $^{7} \cdot$ Erika S. Stippler ${ }^{3}$
}

Received: 3 October 2014 / Accepted: 10 August 2015 / Published online: 19 August 2015

(C) The Author(s) 2015. This article is published with open access at Springerlink.com

\begin{abstract}
Purpose Currently, the FDA allows biowaivers for Class I (high solubility and high permeability) and Class III (high solubility and low permeability) compounds of the Biopharmaceutics Classification System (BCS). Scientific evidence should be provided to support biowaivers for BCS Class I and Class III (high solubility and low permeability) compounds.
\end{abstract}

Methods Data on the effects of excipients on drug permeability are needed to demonstrate that commonly used excipients do not affect the permeability of BCS Class III compounds, which would support the application of biowaivers to Class III compounds. This study was designed to generate such data by assessing the permeability of four BCS Class III compounds and one Class I compound in the presence and absence of five commonly used excipients.

Results The permeability of each of the compounds was assessed, at three to five concentrations, with each excipient in two different models: Caco-2 cell monolayers, and in situ rat intestinal perfusion. No substantial increases in the permeability of any of the compounds were observed in the presence of

\footnotetext{
Chris Bode

cbode@absorption.com

GlaxoSmithKline Inc., Research Triangle Park, North Carolina 27709 USA

2 Absorption Systems LP, Exton, Pennsylvania 19341-2556, USA

3 US Pharmacopeial Convention, Rockville, Maryland 20852, USA

4 Teva Branded Pharmaceuticals R\&D Inc., West Chester, Pennsylvania 19380, USA

5 P'Kinetics International, Inc., Pembroke Pines, Florida 33027, USA

6 Pfizer Global Research and Development, Groton, Connecticut 06340, USA

7 Food and Drug Administration, Office of Generic Drugs, Silver Spring, Maryland 2084I, USA
}

any of the tested excipients in either of the models, with the exception of disruption of Caco-2 cell monolayer integrity by sodium lauryl sulfate at $0.1 \mathrm{mg} / \mathrm{ml}$ and higher.

Conclusion The results suggest that the absorption of these four BCS Class III compounds would not be greatly affected by the tested excipients. This may have implications in supporting biowaivers for BCS Class III compounds in general.

KEY WORDS BCS class III · bioavailability · Caco-2 . permeability r rat intestinal perfusion model

$\begin{array}{ll}\text { ABBREVIATIONS } \\ \text { BA } & \text { Bioavailability } \\ \text { BCS } & \text { Biopharmaceutics classification system } \\ \text { BE } & \text { Bioequivalence } \\ \text { IR } & \text { Immediate-release } \\ \text { KRB } & \text { Krebs Ringers buffer } \\ \text { LC-MS/ } & \text { Liquid chromatography-tandem mass } \\ \text { MS } & \text { spectroscopy } \\ \text { LY } & \text { Lucifer yellow } \\ \text { MES } & \text { 2-(N-morpholino)ethanesulfonic acid } \\ \text { NEAA } & \text { Non-essential amino acids } \\ \text { Papp } & \text { Apparent permeability coefficient } \\ \text { PEG } & \text { Polyethylene glycol } \\ \text { PK } & \text { Pharmacokinetics } \\ \text { SD } & \text { Standard deviation } \\ \text { SEM } & \text { Standard error of the mean }\end{array}$

\section{INTRODUCTION}

The Biopharmaceutics Classification System (BCS) is a framework for classifying drug substances based upon their aqueous solubility and permeability across biological membranes (1). The FDA BCS guidance (2) provides recommendations for 
sponsors of investigational new drug applications (INDs), new drug applications (NDAs), abbreviated new drug applications (ANDAs), and supplements to these applications (SNDA) who wish to request a waiver of in vivo bioequivalence (BE) studies for immediate-release (IR) solid oral dosage forms. Drug substances are classified based on their intestinal permeability (or the fraction of oral dose absorbed) and aqueous solubility at multiple $\mathrm{pH}$ values covering the range found in the gastrointestinal (GI) tract. The solubility class boundary is based according to Papadopoulou et al. (3) the highest dose strength of the drug substance in a pharmaceutical product that is dissolved in $250 \mathrm{ml}$ (8 oz.) of aqueous buffer.

Class I drugs have high permeability, and high solubility at all $\mathrm{pH}$ values between 1.0 and 7.5 (original FDA guidance from 2000), between 1.0 and 6.8 (new FDA draft guidance, May 2015) (2) or between 1.2 and 6.8 (European Medicines Agency (EMA) and World Health Organization (WHO) (4,5); such compounds are well absorbed but may have poor bioavailability (BA) due to extensive first-pass metabolism. Class II compounds have high permeability, but their solubility is below the class boundary at one or more $\mathrm{pH}$ values (e.g., at low $\mathrm{pH}$ for acids or at neutral $\mathrm{pH}$ for bases). The fraction absorbed may be limited by their solubility; therefore, it is not uncommon to see a wide range of extent of absorption for this class of compounds. Class III drugs have low permeability and high solubility, and their fraction absorbed is sometimes limited by their permeability. Class IV drugs have both low permeability and low solubility.

Class I drugs can be granted waivers from in vivo BE testing ("biowaivers") due to their consistently high fraction absorbed, regardless of formulation (6). Several authors have suggested that Class III compounds should also be eligible for biowaivers if a new formulation does not change the permeability or the GI transit time of the drug (7-9). WHO recommends, and the new FDA draft guidance (2) makes provision for, biowaivers for BCS Class III drug products, but only in cases where the generic and comparator drug products are very rapidly dissolving and the excipients meet certain criteria (e.g., qualitatively the same, quantitatively very similar, well-established for use in products containing that drug substance, do not affect GI motility or interactions with transport processes, and do not affect the pharmacokinetics (PK) of the drug substance) $(2,5)$. This suggestion has also been proposed based upon a theoretical assessment of drug BA $(10,11)$.

Certain excipients have been shown either to enhance the in vitro permeability of drugs (e.g., by changing membrane integrity or affecting transporters) or to modify GI transit time $(12,13)$. Limited human data also suggest that some excipients may alter the BA of BCS Class III drugs $(14,15)$. Several of these excipients have been demonstrated to alter membrane permeability directly, but others may work by inhibiting secretory transport mechanisms (16).
In order to determine if a new formulation of a BCS III drug is suitable for a biowaiver, the potential effect $(\mathrm{s})$ of the excipient(s) on permeability need to be evaluated. If no effect can be discerned in a well-validated in vitro model, it is reasonable to expect no change in permeability in vivo as well (17-21). First described for this purpose in 1989 (17), the utility of the Caco-2 cell monolayer model for qualitative (e.g., rank-order or high vs. low) prediction of the oral absorption of drugs has been validated repeatedly since then (18-21).

This series of experiments had three objectives: 1) to determine whether a series of commonly used excipients would alter the permeability of model drug compounds in both a Caco-2 cell monolayer system (in vitro model) and an in situ rat intestinal perfusion model (surrogate for human in vivo data); 2) to determine whether there was a correlation between the Caco-2 and in situ rat intestinal perfusion models; and 3) to evaluate the relative suitability of the two models for testing the effects of excipients. The excipients were selected on the basis of their aqueous solubility and prevalence in IR formulations.

Five excipients were selected for testing: hydroxypropyl methylcellulose (HPMC), povidone, polyethylene glycol (PEG)-400, sodium lauryl sulfate (SLS), and lactose. All of these are commonly used in oral formulations, and some have been shown to act as penetration enhancers (16). The model compounds evaluated for permeability were antipyrine (BCS Class I), acyclovir (Class III), atenolol (Class III), ganciclovir (Class III), and nadolol (Class III) (22). The Class III compounds were selected because they are not substrates of P-gp and because they represent a range of the in vivo fraction absorbed, with atenolol $>$ nadolol $>$ acyclovir $>$ ganciclovir (23). Antipyrine was included as a highly permeable control compound.

\section{MATERIALS AND METHODS}

\section{Materials}

Ganciclovir was obtained from Toronto Research Chemicals (Toronto, Ontario, Canada). Acyclovir, antipyrine, atenolol, nadolol, digoxin, propranolol, D-glucose, D-lactose monohydrate, povidone K15, HPMC, PEG-400, SLS, 2- $(\mathcal{N}-$ morpholino)ethanesulfonic acid (MES), and Krebs Ringers buffer (KRB) were obtained from Sigma-Aldrich (St. Louis, MO, USA). Lucifer yellow (LY), Hanks' balanced salt solution (HBSS), Dulbecco's modified Eagle's medium (DMEM), and 4-(2-hydroxyethyl)-1-piperazineethanesulfonic acid (HEPES) were obtained from Invitrogen (Carlsbad, CA, USA). Fetal bovine serum (FBS) was obtained from Omega (Tarzana, CA, USA). Penicillin, streptomycin, non-essential amino acids (NEAA), and trypsin-EDTA were obtained from CelGro (Herndon, VA, USA). Costar ${ }^{\circledR}$ tissue culture flasks and dual- 
chamber Transwell ${ }^{\circledR}$ plates were obtained from Corning (Corning, NY, USA).

The excipients used and their respective concentrations are given in Table I. The selection of the excipients and the concentrations used in the study were based on information obtained from the FDA's Inactive Ingredient Database (24). The inclusion criteria for selection of the excipient and the concentrations included the frequency at which the excipient is used (they are all commonly used), the amount of excipient typically used, the solubility of the excipient in physiological fluids, and the concentration of the excipient in the commonly used dosing volume of $250 \mathrm{ml}$. This may be an important factor in determining the choice of excipients in new formulations.

\section{Bioanalysis}

A liquid chromatography-tandem mass spectroscopy (LCMS/MS) analytical method was developed and validated for the simultaneous determination of the five compounds (acyclovir, antipyrine, atenolol, ganciclovir, and nadolol) in the presence of five excipients (HPMC, povidone, PEG-400, SLS, and lactose). The analytical system was a PE SCIEX API 3000 LC-MS/MS with Flux Instruments Rheos 2000 pumps, a CTC Analytics autosampler, and an on-line degassing system. The LG column was a Thermo Aquasil C18 $(3 \mu \mathrm{m}, 50 \times 2.1 \mathrm{~mm})$ run at $300 \mu \mathrm{l} / \mathrm{min}$ with a 9 -min gradient from $90 \%$ water $/ 10 \%$ ammonium formate buffer (40 mM, pH 3.5) to $90 \%$ acetonitrile/10\% ammonium formate buffer. Accuracy, based on analysis of replicate standards at $1 \mu \mathrm{M}$, was between 98.8 and $107 \%$ for all analytes, with coefficients of variation ranging from 2.6 to $5.9 \%$. Similar accuracy and precision were found at lower concentrations.

\section{Caco-2 Cells}

Caco-2 cells (clone C2BBel) were cultured in DMEM supplemented with $10 \% \mathrm{FBS}, 1 \mathrm{mM}$ sodium pyruvate, $100 \mu \mathrm{M}$ NEAA, $2 \mathrm{mM}$ L-glutamine, $100 \mathrm{U} / \mathrm{ml}$ penicillin, and $100 \mu \mathrm{g} / \mathrm{ml}$ streptomycin. Stock cultures were grown in 175$\mathrm{cm}^{2}$ flasks at $37^{\circ} \mathrm{C}$ in a humidified atmosphere containing $5 \%$ $\mathrm{CO}_{2}$. Cells were harvested with trypsin-EDTA, seeded at a density of 60,000 cells $/ \mathrm{cm}^{2}$ on collagen-coated Transwell plates $\left(0.4-\mu \mathrm{m}\right.$ pore size), and grown at $37^{\circ} \mathrm{C}$ in a humidified atmosphere containing $5 \% \mathrm{CO}_{2}$. The culture medium was changed every other day for 10 days, and daily thereafter. Cell monolayers on Transwell plates were used for transport assays between 21 and 28 days post- seeding. Prior to use, each batch of monolayers was certified by measuring the transepithelial electrical resistance and the permeability of atenolol, propranolol, LY, and digoxin.

\section{Permeability Across Caco-2 Cell Monolayers}

Non-specific Binding and Recovery Assessment

Acyclovir $(100 \mu \mathrm{M})$, antipyrine $(10 \mu \mathrm{M})$, atenolol $(100 \mu \mathrm{M})$, ganciclovir $(100 \mu \mathrm{M})$, and nadolol $(100 \mu \mathrm{M})$ were dosed together as a cassette in the apical chamber of a cell-free Transwell device ( $n=3$ replicates) to determine the non-specific binding (recovery) and cell-free apparent permeability across the membrane of each compound. Samples were collected from the donor and receiver chambers at multiple time points and analyzed by LC-MS/MS. "Cassette" refers to a small set of drugs (e.g., 3-5) or other compounds that are dosed together (codosed) for evaluation of their permeability (in vitro), absorption (in situ), or BA (in vivo). The assumption is that they do not interact with each other or interfere with each other's absorption, in which case the co-dosed results should reflect the results that would be obtained if they were dosed individually.

\section{Permeability Assay}

The unidirectional (apical-to-basolateral $(\mathrm{A} \rightarrow \mathrm{B}))$ and bidirectional $(\mathrm{A} \rightarrow \mathrm{B}$ and $\mathrm{B} \rightarrow \mathrm{A})$ permeability of acyclovir, antipyrine, atenolol, ganciclovir, and nadolol, dosed as a cassette, was determined with Caco-2 cell monolayers. Bidirectional permeability was measured in the absence of excipients only $(n=3$ replicates), whereas unidirectional permeability was measured both in the presence and absence of excipients $n=4$ replicates). The transport buffer was HBSS, supplemented with $10 \mathrm{mM}$ MES or HEPES buffer and $10 \mathrm{mM}$ D-glucose (15 mM D-glucose final concentration). The $\mathrm{pH}$ of the buffer in the apical $(\mathrm{A} \rightarrow \mathrm{B}$ donor, $\mathrm{B} \rightarrow \mathrm{A}$ receiver $)$ chamber was 6.8, and the $\mathrm{pH}$ of the buffer in the basolateral $(\mathrm{A} \rightarrow \mathrm{B}$ receiver, $\mathrm{B} \rightarrow \mathrm{A}$ donor) chamber was 7.4. The apparent permeability $\left(P_{\text {app }}\right)$ and recovery were calculated as follows:

$$
\begin{aligned}
& P_{\text {app }}=\left(d C_{r} / d t\right) \times V_{r} /\left(A \times C_{0}\right) \\
& \text { Percent Recovery }=100 \\
& \qquad \times\left[\left(V_{\mathrm{r}} \times C_{\mathrm{rfinal}}\right)+\left(V_{\mathrm{d}} \times C_{\mathrm{d} \text { final }}\right)\right] /\left(V_{\mathrm{d}} \times C_{0}\right) \\
& \qquad \begin{array}{l}
\text { Efflux ratio } \stackrel{\text { app }(B \rightarrow A)}{=} /(A \rightarrow B) \\
\text { app }
\end{array}
\end{aligned}
$$

$d C_{\mathrm{r}} / d t$ is the rate of appearance of the compound in the receiver compartment $(\mu \mathrm{M} / \mathrm{sec}) ; V_{\mathrm{r}}$ and $V_{\mathrm{d}}$ are the volumes of the receiver and donor compartments, respectively $\left(\mathrm{cm}^{3}\right) ; A$ is the surface area of the cell monolayer $\left(1.13 \mathrm{~cm}^{2}\right) ; C_{0}$ is the concentration $(\mu \mathrm{M})$ of the dosing solution; and $C_{\mathrm{r} \text { final }}$ and $C_{\mathrm{d}}$ final are the concentrations $(\mu \mathrm{M})$ in the receiver and donor compartments, respectively, at the end of the incubation period. 
Table I Concentrations of Excipients Tested in the Two Permeability Models

\begin{tabular}{lll}
\hline Excipient & Concentrations In Caco-2 $(\mathrm{mg} / \mathrm{ml})$ & Concentrations in rat intestinal perfusion $(\mathrm{mg} / \mathrm{ml})$ \\
\hline Lactose & $0.024,0.13,0.24,1.0,2.0$ & $0.024,0.13,0.24$ \\
HPMC & $0.012,0.036,0.06,1.0,2.0$ & $0.012,0.036,0.06$ \\
PEG-400 & $0.015,0.06,0.18,0.30$ & $0.06,0.18,0.30$ \\
Povidone & $0.024,0.042,0.06,0.1,0.2$ & $0.024,0.042,0.06$ \\
SLS & $0.01,0.02,0.04,0.10,0.17$ & $0.01,0.02,0.04,0.17$ \\
\hline
\end{tabular}

\section{Permeability Across Rat Jejunum in Recirculating Intestinal Perfusion Model}

\section{Test System}

Sprague-Dawley rats (300-350 g) were used to perform closed-loop, in situ intestinal perfusion. Rats were fasted for 12-18 h before the experiment, and water was supplied ad libitum.

\section{Study Design}

Four rats $(n=4)$ were used per treatment group, with a total of 17 groups: one control group (assay buffer, no excipients) and three or four treatment groups for each of the five excipients, with a different concentration for each group. The recirculating intestinal perfusion was performed with the five compounds dosed as a cassette $(100 \mu \mathrm{M}$ acyclovir, $10 \mu \mathrm{M}$ antipyrine, $100 \mu \mathrm{M}$ atenolol, $100 \mu \mathrm{M}$ ganciclovir, and $100 \mu \mathrm{M}$ nadolol) in $\mathrm{KRB}$ with $10 \mathrm{mM}$ MES, pH 6.8.

\section{Test Method}

Rats were anesthetized with an intraperitoneal injection of ketamine/xylazine $(1 \mathrm{ml} / \mathrm{kg})$ and placed on a heating pad to maintain normal body temperature. After making a midline incision, the intestines were externalized. A $10-\mathrm{cm}$ segment of the jejunum was tied off, cannulated at both ends to form a loop, and flushed with saline and air. The loop was equilibrated statically with dosing solution for $30 \mathrm{~min}$, then flushed with air and perfused by recirculation (peristaltic pump) with $10 \mathrm{ml}$ dosing solution at $0.2 \mathrm{ml} / \mathrm{min}$. Samples of the perfusate were taken from the reservoir at 15, 30, 45, 60, 75, and $90 \mathrm{~min}$ for analysis by LC-MS/MS.

\section{Sample and Data Analysis}

The effective permeability coefficient, $\mathrm{P}_{\text {eff }}(\mathrm{cm} / \mathrm{s})$, was calculated as

$P_{e f f}=-\left(d\left(\ln \left[C / C_{0}\right]\right) / d t\right) \times V / 2 \pi r l$

where $C$ is the concentration at a given time and $C_{0}$ is the concentration in the dosing solution $(\mu \mathrm{M}) ; d\left(\ln C / C_{0}\right) / d t$ is the slope of a plot of the natural log of the concentration ratio in the perfusate $v s$. time $\left(\mathrm{sec}^{-1}\right)$ at steady state, corrected for the apparent loss (due to dilution) of the impermeant marker FD4 (fluorescein-conjugated dextran with a molecular weight of $4 \mathrm{kDa}) ; V$ is the volume of the dosing solution $\left(10 \mathrm{~cm}^{3}\right) ; 2 \pi r l$ is the luminal surface area $\left(\mathrm{cm}^{2}\right)$, based on a radius $(r)$ of $0.178 \mathrm{~cm}$ for the rat intestine (25) and the measured length of each intestinal segment, $l(\mathrm{~cm})$.

\section{RESULTS}

\section{LC-MS/MS}

The LC-MS/MS method for acyclovir, antipyrine, atenolol, ganciclovir, and nadolol cassette analysis - in the presence and absence of the excipients HPMC, povidone, PEG-400, SLS, and lactose - had adequate sensitivity and selectivity and was valid for use in this study. The lower limit of quantification (LLOQ) was $0.005 \mu \mathrm{M}$, and the upper limit of quantification (ULOQ) was $1 \mu \mathrm{M}$ for all analytes. The intra- and inter-assay accuracy and precision were within $\pm 12 \%$ of nominal at all concentration levels in all three matrices (HBSSg, $\mathrm{pH} 7.4$; HBSSg, pH 6.8; and KRB, pH 6.8). Benchtop, autosampler, and refrigerator stability were adequate, and no significant endogenous interference was found from HPMC, povidone, SLS, PEG-400, or lactose.

Table II Non-specific Binding and Recovery of Antipyrine, Acyclovir, Atenolol, Ganciclovir and Nadolol from Cell-Free Permeability Test Devices

\begin{tabular}{llr}
\hline Compound $(\mu \mathrm{M})$ & Cell-free $P_{\text {app }}\left(10^{-6} \mathrm{~cm} / \mathrm{s}\right)^{\mathrm{a}}$ & Recovery $(\%)$ \\
\hline Acyclovir (I00) & $29.8 \pm 1.8$ & $86.1 \pm 1.7$ \\
Antipyrine (10) & $34.8 \pm 0.8$ & $85.8 \pm 2.1$ \\
Atenolol (I00) & $33.8 \pm 0.7$ & $102 \pm 1.1$ \\
Ganciclovir (100) & $31.1 \pm 1.4$ & $92.3 \pm 1.6$ \\
Nadolol (I00) & $33.0 \pm 0.7$ & $101 \pm 1.5$ \\
\hline
\end{tabular}

Data presented as mean $\pm \mathrm{SD}, n=3$

a For example, a value of "I.0" represents a $P_{\text {app }}$ of $1.0 \times 10^{-6} \mathrm{~cm} / \mathrm{s}$ 
Table III Bidirectional Permeability and Recovery of Antipyrine, Acyclovir, Atenolol, Ganciclovir and Nadolol Across Caco-2 Cell Monolayers

\begin{tabular}{|c|c|c|c|c|c|}
\hline \multirow[t]{2}{*}{ Compound $(\mu M)$} & \multicolumn{2}{|l|}{$A \rightarrow B$} & \multicolumn{2}{|l|}{$B \rightarrow A$} & \multirow[t]{2}{*}{ Efflux ratio ${ }^{b}$} \\
\hline & $P_{\text {app }}\left(10^{-6} \mathrm{~cm} / \mathrm{s}\right)^{a}$ & Recovery (\%) & $P_{\text {app }}\left(10^{-6} \mathrm{~cm} / \mathrm{s}\right)^{a}$ & Recovery (\%) & \\
\hline Acyclovir (100) & $0.32 \pm 0.14$ & $82.2 \pm 8.6$ & $0.85 \pm 0.11$ & $94.9 \pm 12.2$ & 2.7 \\
\hline Antipyrine (10) & $44.5 \pm 0.70$ & $104 \pm 3.1$ & $52.5 \pm 3.80$ & $98.8 \pm 9.60$ & 1.2 \\
\hline Atenolol (I00) & $0.29 \pm 0.14$ & $83.6 \pm 9.2$ & $0.62 \pm 0.08$ & $94.0 \pm 11.0$ & 2.2 \\
\hline Ganciclovir (I00) & $0.32 \pm 0.16$ & $82.9 \pm 7.3$ & $0.70 \pm 0.09$ & $92.7 \pm 10.8$ & 2.1 \\
\hline Nadolol (100) & $0.29 \pm 0.16$ & $83.9 \pm 9.1$ & $0.7 I \pm 0.15$ & $90.7 \pm 12.2$ & 2.5 \\
\hline
\end{tabular}

Data presented as mean $\pm \mathrm{SD}, n=3$

a For example, a value of " 1.0 " represents a $P_{\text {app }}$ of $1.0 \times 10^{-6} \mathrm{~cm} / \mathrm{s}$

${ }^{\mathrm{b}}$ Efflux ratio is calculated from the mean $\mathrm{P}_{\text {app }}$ value in each direction

Table IV Effects of Excipients on In Vitro Caco-2 Cell Monolayer Permeability

\begin{tabular}{|c|c|c|c|c|c|c|}
\hline \multirow[t]{2}{*}{ Excipient } & \multirow[t]{2}{*}{ Conc., mg/ml } & \multicolumn{5}{|c|}{ Apparent permeability coefficient $\left(\mathrm{P}_{\text {app }}\right)\left(10^{-6} \mathrm{~cm} / \mathrm{s}\right)$} \\
\hline & & Antipyrine & Acyclovir & Atenolol & Ganciclovir & Nadolol \\
\hline Control $^{\mathrm{a}}$ & & $39.9 \pm 2.14$ & $0.28 \pm 0.06$ & $0.23 \pm 0.05$ & $0.25 \pm 0.06$ & $0.21 \pm 0.06$ \\
\hline Control $^{b}$ & & $43.6 \pm 0.89$ & $0.28 \pm 0.06$ & $0.25 \pm 0.05$ & $0.22 \pm 0.05$ & $0.21 \pm 0.04$ \\
\hline \multirow[t]{5}{*}{ D-Lactose } & $0.024^{\mathrm{a}}$ & $42.3 \pm 5.53$ & $0.18 \pm 0.04$ & $0.19 \pm 0.05$ & $0.14 \pm 0.04$ & $0.14 \pm 0.04$ \\
\hline & $0.13^{\mathrm{a}}$ & $41.6 \pm 0.58$ & $0.32 \pm 0.11$ & $0.57 \pm 0.46$ & $0.48 \pm 0.42$ & $0.44 \pm 0.37$ \\
\hline & $0.24^{\mathrm{a}}$ & $39.8 \pm 0.55$ & $0.31 \pm 0.20$ & $0.27 \pm 0.19$ & $0.28 \pm 0.19$ & $0.27 \pm 0.20$ \\
\hline & $1.0^{\mathrm{b}}$ & $33.3 \pm 0.85$ & $0.20 \pm 0.05$ & $0.16 \pm 0.06$ & $0.17 \pm 0.05$ & $0.14 \pm 0.05$ \\
\hline & $2.0^{\mathrm{b}}$ & $33.1 \pm 1.32$ & $0.17 \pm 0.14$ & $0.14 \pm 0.01$ & $0.16 \pm 0.01$ & $0.13 \pm 0.01$ \\
\hline \multirow[t]{5}{*}{ Povidone } & $0.024^{a}$ & $44.5 \pm 0.91$ & $0.17 \pm 0.02$ & $0.14 \pm 0.01$ & $0.15 \pm 0.01$ & $0.11 \pm 0.01$ \\
\hline & $0.042^{\mathrm{a}}$ & $40.4 \pm 0.96$ & $0.21 \pm 0.03$ & $0.15 \pm 0.02$ & $0.18 \pm 0.03$ & $0.13 \pm 0.02$ \\
\hline & $0.06^{\mathrm{a}}$ & $41.9 \pm 0.30$ & $0.14 \pm 0.004$ & $0.11 \pm 0.003$ & $0.12 \pm 0.002$ & $0.09 \pm 0.02$ \\
\hline & $0.1^{\mathrm{b}}$ & $38.5 \pm 1.56$ & $0.19 \pm 0.05$ & $0.13 \pm 0.03$ & $0.16 \pm 0.04$ & $0.12 \pm 0.03$ \\
\hline & $0.2^{b}$ & $36.3 \pm 0.56$ & $0.23 \pm 0.06$ & $0.16 \pm 0.05$ & $0.19 \pm 0.05$ & $0.15 \pm 0.05$ \\
\hline \multirow[t]{5}{*}{ HPMC } & $0.012^{\mathrm{a}}$ & $40.8 \pm 0.99$ & $0.15 \pm 0.01$ & $0.12 \pm 0.01$ & $0.14 \pm 0.01$ & $0.11 \pm 0.01$ \\
\hline & $0.036^{\mathrm{a}}$ & $37.3 \pm 1.33$ & $0.18 \pm 0.04$ & $0.14 \pm 0.04$ & $0.15 \pm 0.04$ & $0.14 \pm 0.03$ \\
\hline & $0.06^{\mathrm{a}}$ & $39.2 \pm 1.63$ & $0.17 \pm 0.05$ & $0.14 \pm 0.05$ & $0.15 \pm 0.05$ & $0.14 \pm 0.05$ \\
\hline & $1.0^{\mathrm{b}}$ & $33.2 \pm 1.51$ & $0.20 \pm 0.06$ & $0.15 \pm 0.05$ & $0.16 \pm 0.05$ & $0.13 \pm 0.05$ \\
\hline & $2.0^{b}$ & $33.5 \pm 0.29$ & $0.17 \pm 0.03$ & $0.13 \pm 0.02$ & $0.15 \pm 0.03$ & $0.11 \pm 0.02$ \\
\hline \multirow[t]{5}{*}{ SLS } & $0.01^{a}$ & $46.9 \pm 2.50$ & $0.25 \pm 0.07$ & $0.24 \pm 0.07$ & $0.21 \pm 0.07$ & $0.23 \pm 0.07$ \\
\hline & $0.02^{\mathrm{a}}$ & $40.9 \pm 1.11$ & $0.34 \pm 0.04$ & $0.32 \pm 0.05$ & $0.30 \pm 0.04$ & $0.31 \pm 0.05$ \\
\hline & $0.04^{\mathrm{a}}$ & $45.9 \pm 0.56$ & $0.35 \pm 0.11$ & $0.39 \pm 0.12$ & $0.30 \pm 0.10$ & $0.31 \pm 0.10$ \\
\hline & $0.1^{a, c}$ & $36.6 \pm 1.23$ & $2.48 \pm 1.08$ & $2.14 \pm 0.96$ & $2.23 \pm 0.98$ & $1.98 \pm 0.87$ \\
\hline & 0.17 & \multicolumn{5}{|c|}{ Not determined due to disruption of monolayer integrity } \\
\hline \multirow[t]{4}{*}{ PEG 400} & $0.015^{b}$ & $40.7 \pm 0.96$ & $0.34 \pm 0.04$ & $0.29 \pm 0.04$ & $0.30 \pm 0.04$ & $0.27 \pm 0.04$ \\
\hline & $0.06^{\mathrm{a}}$ & $38.9 \pm 0.49$ & $0.17 \pm 0.01$ & $0.17 \pm 0.01$ & $0.16 \pm 0.01$ & $0.13 \pm 0.01$ \\
\hline & $0.18^{\mathrm{a}}$ & $37.2 \pm 0.53$ & $0.22 \pm 0.06$ & $0.18 \pm 0.05$ & $0.20 \pm 0.05$ & $0.14 \pm 0.04$ \\
\hline & $0.30^{\mathrm{a}}$ & $37.2 \pm 0.68$ & $0.19 \pm 0.06$ & $0.16 \pm 0.05$ & $0.18 \pm 0.05$ & $0.12 \pm 0.04$ \\
\hline
\end{tabular}

Data presented as mean $\pm \operatorname{SEM}(n=4)$

a,b Two separate sets of controls were run, each in parallel with a batch of test wells with excipients

${ }^{c}$ Integrity of Caco-2 cell monolayers was compromised ( $L Y P_{\text {app }} 0.18 \times 10^{-6} \mathrm{~cm} / \mathrm{s}$ with buffer only; $0.30 \times 10^{-6} \mathrm{~cm} / \mathrm{s}$ with test compounds only (no excipients); $0.05 \times 10^{-6} \mathrm{~cm} / \mathrm{s}$ with $0.01 \mathrm{mg} / \mathrm{ml} \mathrm{SLS} ; 0.16 \times 10^{-6} \mathrm{~cm} / \mathrm{s}$ with $0.02 \mathrm{mg} / \mathrm{ml}$ $\mathrm{SLS} ; 0.20 \times 10^{-6} \mathrm{~cm} / \mathrm{s}$ with $0.04 \mathrm{mg} / \mathrm{ml} \mathrm{SLS} ; 2.20 \times 10^{-6} \mathrm{~cm} / \mathrm{s}$ with $0.1 \mathrm{mg} / \mathrm{ml} \mathrm{SLS} ; 4.61 \times 10^{-6} \mathrm{~cm} / \mathrm{s}$ with $0.17 \mathrm{mg} / \mathrm{ml} \mathrm{SLS}$ ) 
Table V Effects of Excipients on In Situ Rat Jejunal Permeability

\begin{tabular}{|c|c|c|c|c|c|c|}
\hline \multirow[t]{2}{*}{ Excipient } & \multirow[t]{2}{*}{ Conc., mg/ml } & \multicolumn{5}{|c|}{ Effective permeability coefficient $\left(\mathrm{P}_{\text {eff }}\right)\left(10^{-4} \mathrm{~cm} / \mathrm{s}\right)$} \\
\hline & & Antipyrine & Acyclovir & Atenolol & Ganciclovir & Nadolol \\
\hline \multicolumn{2}{|l|}{ Control } & $1.43 \pm 0.17$ & $-0.42 \pm 0.24$ & $-0.33 \pm 0.22$ & $-0.24 \pm 0.17$ & $-0.41 \pm 0.19$ \\
\hline \multirow[t]{3}{*}{ D-Lactose } & 0.024 & $1.40 \pm 0.20$ & $-0.51 \pm 0.09$ & $-0.53 \pm 0.09$ & $-0.44 \pm 0.09$ & $-0.44 \pm 0.08$ \\
\hline & 0.13 & $1.28 \pm 0.06$ & $-0.09 \pm 0.36$ & $-0.17 \pm 0.36$ & $-0.10 \pm 0.19$ & $-0.21 \pm 0.17$ \\
\hline & 0.24 & $2.03 \pm 0.38$ & $-0.26 \pm 0.22$ & $-0.16 \pm 0.28$ & $-0.11 \pm 0.17$ & $-0.17 \pm 0.24$ \\
\hline \multirow[t]{3}{*}{ Povidone } & 0.024 & $1.63 \pm 0.34$ & $0.16 \pm 0.19$ & $0.21 \pm 0.17$ & $0.05 \pm 0.15$ & $0.13 \pm 0.015$ \\
\hline & 0.042 & $1.15 \pm 0.07$ & $-0.22 \pm 0.24$ & $-0.20 \pm 0.21$ & $-0.10 \pm 0.18$ & $-0.11 \pm 0.16$ \\
\hline & 0.06 & $1.33 \pm 0.42$ & $0.03 \pm 0.14$ & $0.12 \pm 0.15$ & $-0.25 \pm 0.09$ & $-0.23 \pm 0.08$ \\
\hline \multirow[t]{3}{*}{ HPMC } & 0.012 & $1.43 \pm 0.21$ & $0.35 \pm 0.18$ & $0.36 \pm 0.19$ & $0.10 \pm 0.17$ & $0.07 \pm 0.17$ \\
\hline & 0.036 & $0.91 \pm 0.19$ & $0.05 \pm 0.06$ & $0.00 \pm 0.07$ & $-0.04 \pm 0.03$ & $-0.12 \pm 0.03$ \\
\hline & 0.06 & $1.68 \pm 0.35$ & $0.21 \pm 0.14$ & $0.06 \pm 0.03$ & $0.27 \pm 0.07$ & $0.40 \pm 0.07$ \\
\hline \multirow[t]{4}{*}{ SLS } & 0.01 & $1.75 \pm 0.23$ & $0.19 \pm 0.012$ & $0.46 \pm 0.13$ & $0.23 \pm 0.15$ & $0.32 \pm 0.15$ \\
\hline & 0.02 & $0.93 \pm 0.26$ & $0.4 I \pm 0.07$ & $0.46 \pm 0.09$ & $0.36 \pm 0.07$ & $0.37 \pm 0.10$ \\
\hline & 0.04 & $1.08 \pm 0.18$ & $-0.05 \pm 0.07$ & $0.02 \pm 0.05$ & $0.00 \pm 0.01$ & $0.01 \pm 0.02$ \\
\hline & 0.17 & $1.57 \pm 0.46$ & $-0.38 \pm 0.14$ & $-0.30 \pm 0.17$ & $-0.28 \pm 0.14$ & $-0.36 \pm 0.10$ \\
\hline \multirow[t]{4}{*}{ PEG 400} & 0.06 & $1.17 \pm 0.22$ & $0.17 \pm 0.07$ & $0.29 \pm 0.07$ & $0.26 \pm 0.07$ & $0.24 \pm 0.08$ \\
\hline & 0.18 & $0.90 \pm 0.26$ & $0.27 \pm 0.14$ & $0.27 \pm 0.13$ & $0.30 \pm 0.09$ & $0.25 \pm 0.08$ \\
\hline & 0.30 & $0.82 \pm 0.15$ & $0.07 \pm 0.02$ & $0.09 \pm 0.03$ & $0.02 \pm 0.05$ & $0.01 \pm 0.01$ \\
\hline & $0.30^{\mathrm{a}}$ & $1.53 \pm 0.18$ & $-0.21 \pm 0.19$ & $-0.13 \pm 0.20$ & $-0.24 \pm 0.13$ & $-0.23 \pm 0.13$ \\
\hline
\end{tabular}

Data presented as mean $\pm \operatorname{SEM}(n=4)$

${ }^{\text {a }}$ Second run

\section{Bidirectional Permeability}

As shown in Table II, all five compounds in the cassette had recoveries of at least $85 \%$ and high cell-free permeability un$\operatorname{der} \mathrm{A} \rightarrow \mathrm{B}$ test conditions. High recovery indicates little loss to either non-specific binding to the device or chemical instability during the assay, and high cell-free $P_{\text {app }}$ indicates that the compounds were freely diffusible across the membrane (lack of aggregation, etc.).

The bidirectional permeability results presented in Table III demonstrate that the BCS Class I compound antipyrine had much higher permeability across Caco-2 cell monolayers than the other four model compounds in the cassette (all of which were BCS Class III compounds), with complete recovery and no significant efflux (efflux ratio was approximately equal to 1 ). The permeability of acyclovir, atenolol, ganciclovir, and nadolol were each quite low and similar in magnitude to each other; the efflux ratios ranged from 2.1 to 2.7 .

\section{Unidirectional Permeability}

The concentrations of the excipients tested are shown in Table I. The concentrations (in $\mathrm{mg} / \mathrm{ml}$ ) are shown with the two permeability models, Caco-2 cells and rat intestinal perfusion.

The results presented in Table IV demonstrate no consistent, concentration-dependent changes in the permeability of
Fig. I $P_{\text {app }}$ vs. D-Lactose concentration.

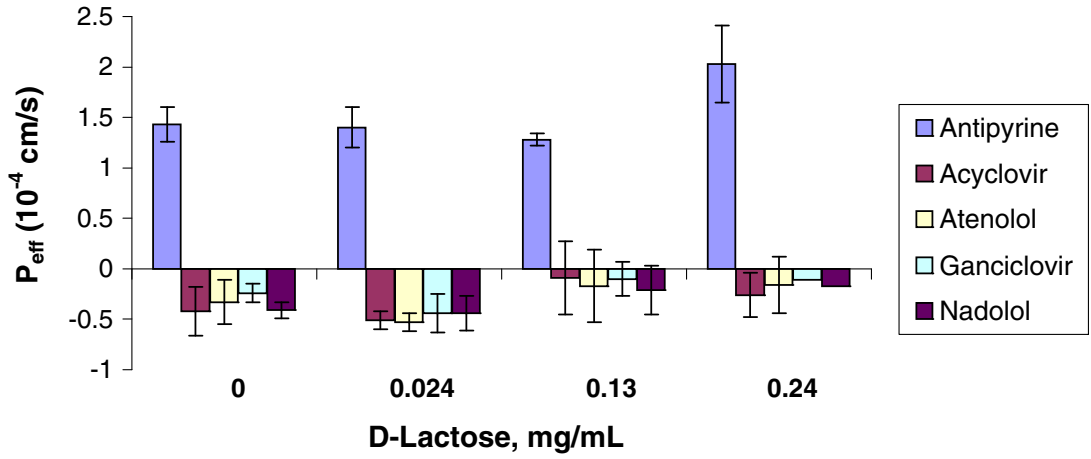


Fig. $2 P_{\text {app }}$ vs. Povidone concentration.

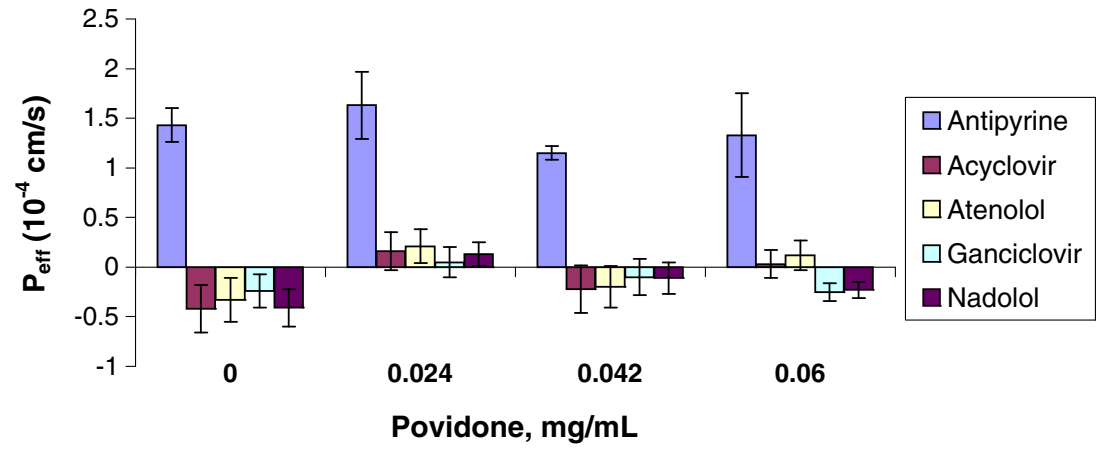

the model compounds across Caco-2 cell monolayers in the $\mathrm{A} \rightarrow \mathrm{B}$ (physiological absorptive) direction in the presence of up to $2.0 \mathrm{mg} / \mathrm{ml}$ lactose, $0.2 \mathrm{mg} / \mathrm{ml}$ povidone, $2.0 \mathrm{mg} / \mathrm{ml}$ $\mathrm{HPMC}, 0.04 \mathrm{mg} / \mathrm{ml} \mathrm{SLS}$, or $0.3 \mathrm{mg} / \mathrm{ml} \mathrm{PEG-400.} \mathrm{The} \mathrm{same}$ was true for monolayer integrity (data not shown). On the other hand, SLS at concentrations of 0.1 and $0.17 \mathrm{mg} / \mathrm{ml}$ increased the post-experiment permeability of the monolayer integrity marker LY, indicative of damage to the cell monolayer (see footnote to Table IV). The permeability of the model compounds in the presence of $0.1 \mathrm{mg} / \mathrm{ml}$ SLS was approximately 10-fold higher than control; permeability in the presence of $0.17 \mathrm{mg} / \mathrm{ml}$ SLS was not determined due to the evident cell monolayer damage.

\section{Permeability in the Recirculating In Situ Rat Intestinal Perfusion Model}

As shown in Table $\mathrm{V}$ and in Figs. 1, 2, 3, 4, and 5, the permeability results in the recirculating in situ rat intestinal perfusion model also suggest that lactose (up to $0.24 \mathrm{mg} / \mathrm{ml}$ ), povidone (up to $0.06 \mathrm{mg} / \mathrm{ml}$ ), HPMC (up to $0.06 \mathrm{mg} / \mathrm{ml}$ ), SLS (up to $0.17 \mathrm{mg} / \mathrm{ml}$ ), and of PEG-400 (up to $0.3 \mathrm{mg} / \mathrm{ml}$ ) do not have a substantial effect on the permeability of the model compounds across rat jejunum. The small sample size precludes definitive conclusions regarding statistical significance.

The permeability data were noticeably less variable in the Caco-2 model than in the in situ rat perfusion model: median relative standard deviation for antipyrine of $2.64 \%$ in the Caco-2 model vs. $18.5 \%$ in the rat perfusion model; a range of 17.0 to $19.4 \%$ for the Class III compounds in the Caco-2 model vs. 46.4 to $65.2 \%$ in the rat perfusion model.

\section{DISCUSSION}

An LC-MS/MS method was validated for acyclovir, antipyrine, atenolol, ganciclovir, and nadolol determinations as a cassette in the absence and presence of excipients. This approach allowed for a relatively rapid assessment of the results of both arms of the study. This approach may be used to test the effects of other excipients on the same model compounds.

The permeability of all five model compounds across intestinal epithelia was measured both in vitro (Caco-2 cell monolayers) and in situ (rat intestinal perfusion). One problem with the intestinal perfusion model is that negative $\mathrm{P}_{\text {eff values }}$ are often observed for low-permeability compounds. The most likely reason for a negative $\mathrm{P}_{\text {eff value is that net water }}$ flux cannot be assessed accurately. When a small amount of a supposedly "impermeable" marker (FD-4 in this case, used to correct for water secretion) is absorbed, mathematically it results in overcorrection for water secretion, resulting in negative $\mathrm{P}_{\text {eff }}$ values for low-permeability compounds. Currently, there are no perfect markers for the rat intestinal perfusion model. FD-4 was used as the impermeable marker in this study, since this marker is widely accepted in the literature. Although negative $\mathrm{P}_{\text {eff }}$ values for low-permeability compounds suggest that the rat perfusion model may be variable and potentially insensitive to small changes in drug

Fig. $3 P_{\text {app }}$ vs. HPMC concentration.

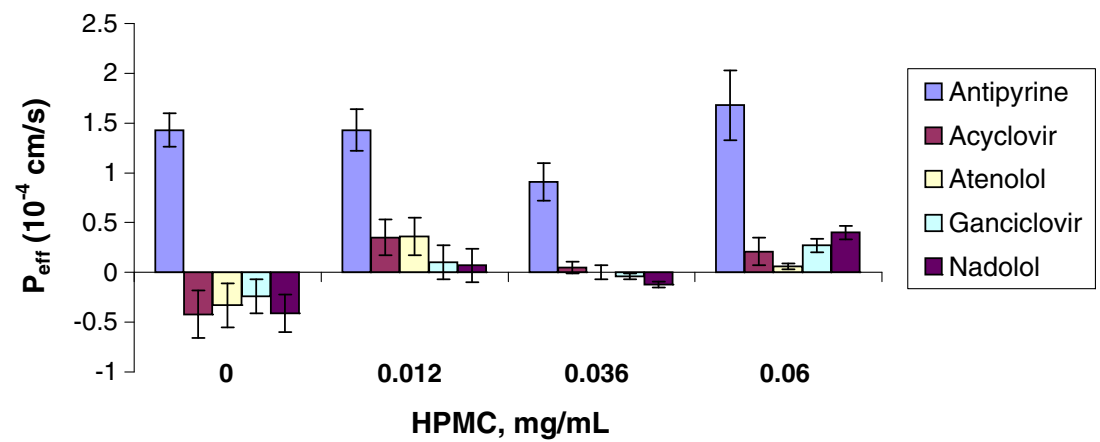


Fig. $4 P_{\text {app }}$ vs. SLS concentration.

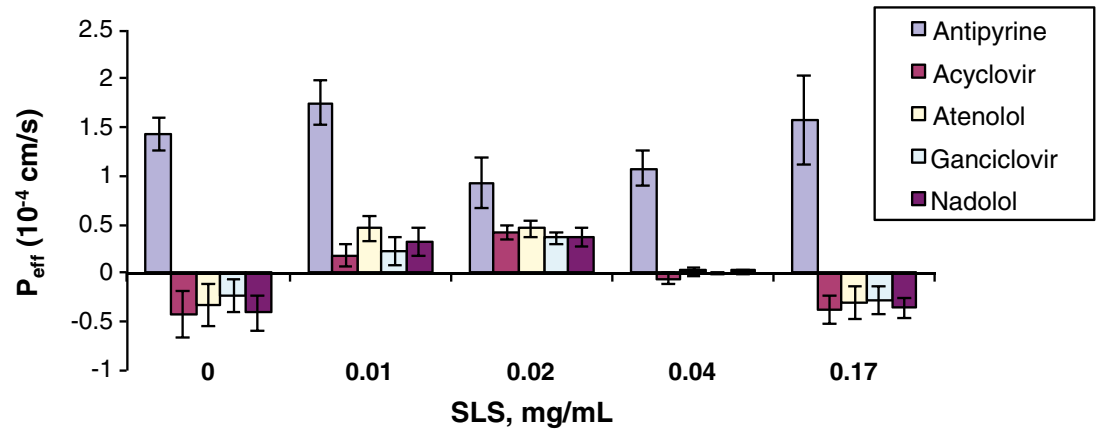

absorption, this system is widely accepted for the evaluation of permeability.

The permeability of the BCS Class I compound antipyrine across Caco-2 cell monolayers was high in both directions, with no asymmetry (ratio of $\mathrm{B} \rightarrow \mathrm{A} P_{\text {app }}$ to $\mathrm{A} \rightarrow \mathrm{B} P_{\text {app }}$ near unity). The Caco-2 $\mathrm{A} \rightarrow \mathrm{B}$ (absorptive direction) permeability of the Class III model compounds acyclovir, atenolol, ganciclovir, and nadolol were all very low and nearly identical in magnitude (between $0.29 \times 10^{-6}$ and $0.32 \times 10^{-6} \mathrm{~cm} / \mathrm{s}$ ). The efflux ratios of the Class III compounds ranged from 2.1 to 2.7, a moderate degree of apparent efflux that is due in part to the fact that, in each case, the recovery was somewhat lower in the $\mathrm{A} \rightarrow \mathrm{B}$ direction than in the $\mathrm{B} \rightarrow \mathrm{A}$ direction, which would tend to underestimate the $P_{\text {app }}$ in the $\mathrm{A} \rightarrow \mathrm{B}$ direction (the denominator in the efflux ratio), leading to an overestimate of efflux. Clinically, linear peak plasma concentration as a function of oral dose $(\mathrm{PK})$ has been reported for atenolol (26) and nadolol (27), suggesting no significant interaction with efflux transporters. For acyclovir (28) and ganciclovir (29), decreasing exposure as a function of dose has been reported after oral administration; this is evidence for possible involvement of active intestinal uptake and is not consistent with an interaction with efflux transporters.

With the exception of an effect of SLS on Caco-2 cell monolayers at concentrations of 0.1 and $0.17 \mathrm{mg} / \mathrm{ml}$, where cell monolayer integrity was clearly compromised, none of the tested excipients caused a substantial increase in the permeability of any of the model compounds in either model. The effect of SLS on Caco-2 cell monolayer integrity at higher test concentrations was clearly a model-specific toxic effect, and therefore may not be pharmaceutically relevant. Other studies have reported positive effects of excipients on the permeability of different drugs, but the effects appear to be dependent on the excipient and its concentration (12,30-32). For example, sorbitol and SLS reduce the bioavailability of the Class I drug risperidone, the former due to increased GI motility and the latter by an unknown mechanism (33). With the exception of SLS at the two highest tested concentrations, the excipients used in this study do not appear to disrupt cell monolayer integrity at the concentrations used, whereas some of the excipients used in other studies (e.g., sodium caprate (31)) may be more likely to do so.

This study focused on the effects of individual excipients on permeability and did not evaluate the effects of combining multiple excipients (which would be commonly done in an IR formulation) on permeability. Because of the vast number of excipient combinations and concentration combinations, testing for the synergistic effects of combinations was not feasible.

While the limitations of the Caco-2 cell monolayer model (like any other preclinical model) are appreciated by investigators in the field, the FDA does accept Caco-2 data for BCS classification. In spite of its limitations, based on the fact that Caco-2 permeability data have lower variability between replicates than data obtained from in situ recirculating rat intestinal perfusion, the Caco-2 cell monolayer model may be more sensitive in terms of detecting effects of an excipient on drug permeability. On the other hand, Caco-2 cell monolayers may be overly sensitive to some excipients, as with SLS at or above $0.1 \mathrm{mg} / \mathrm{ml}$. Therefore, a positive result may need to be followed up in vivo to rule out a false positive.

Fig. $5 P_{\text {app }}$ vs. PEG-400 concentration.

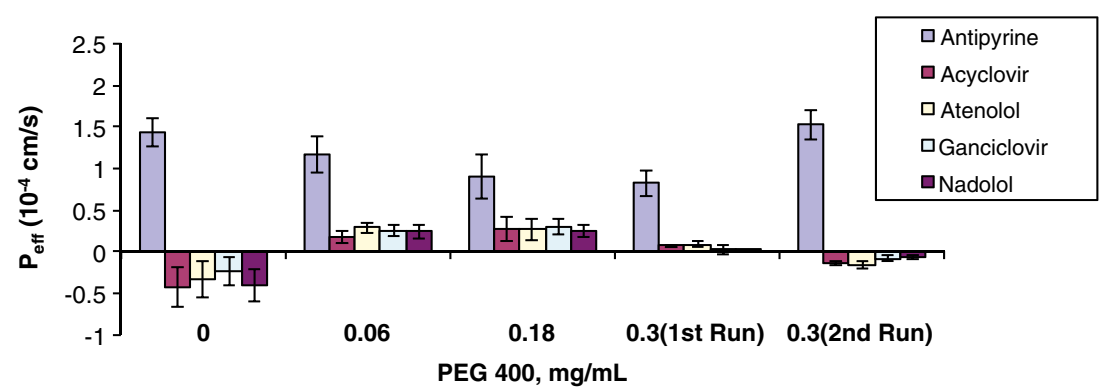


Except for SLS at concentrations at or above $0.1 \mathrm{mg} / \mathrm{ml}$ (at which concentrations the effects are on monolayer integrity rather than due to permeability enhancement), the results of this study with a set of four BCS Class III model compounds support the more general hypothesis that these five commonly used excipients do not affect the permeability of BCS Class III compounds. Biowaivers for Class III compounds should be considered when excipients used in a formulation have been shown not to affect permeability. There are many recent examples of biowaivers granted by the WHO for Class III drugs (34-38), as well as the assessment that BE of many of the IR drug products available today can be assured with an in vitro dissolution test (39). The results of this study support biowaivers for BCS Class III compounds. This would reduce the amount of time needed to get new formulations to patients who need them, reduce the cost of developing new formulations, and reduce the cost of modifying or improving the manufacturing process for products containing Class III drugs. From an ethical point of view, it also reduces the needless exposure of healthy volunteers to drugs without therapeutic benefit.

\section{CONCLUSION}

The influence of five excipients (lactose, povidone, HPMC, SLS, and PEG400), commonly used in IR formulations, on the permeability of five model drugs (acyclovir, antipyrine, atenolol, ganciclovir, and nadolol) was investigated. Two test systems were used: Caco-2 cell monolayers and in situ recirculating rat intestinal perfusion; both have been used for absorption enhancement studies. Within the tested concentration range for all drug-excipient combinations, the excipients caused no substantial increases in drug permeability, except in the case of SLS at concentrations $(0.1 \mathrm{mg} / \mathrm{ml}$ and higher) where cell monolayer integrity was compromised. These results should support biowaivers for BCS Class III (high solubility-low permeability) compounds, but only for compounds similar in permeability to those tested and which have been formulated with the excipients used in this study.

\section{ACKNOWLEDGMENTS AND DISCLOSURES}

The authors extend special thanks to the Product Quality Research Institute (PQRI) and Absorption Systems for their financial support of this work and declare no potential conflicts of interest.

Disclaimer The views expressed in this paper are those of the authors and should not be interpreted as those of the FDA.

Open Access This article is distributed under the terms of the Creative Commons Attribution 4.0 International License (http://creativecommons.org/licenses/by/4.0/), which permits unrestricted use, distribution, and reproduction in any medium, provided you give appropriate credit to the original author(s) and the source, provide a link to the Creative Commons license, and indicate if changes were made.

\section{REFERENCES}

1. Amidon GL, Lennemäs H, Shah VP, Crison JR. A theoretical basis for a biopharmaceutic drug classification: the correlation of in vitro drug product dissolution and in vitro bioavailability. Pharm Res. 1995;12(3):413-20.

2. Guidance for industry. Waiver of in vivo bioavailability and bioequivalence studies for immediate-release solid oral dosage forms based on a biopharmaceutics classification system. U.S. Department of Health and Human Services, Food and Drug Administration, Center for Drug Evaluation and Research (CDER). Bethesda, MD; Aug 2000 (updated May 2015).

3. Papadopoulou V, Valsami G, Dokoumetzidis A, Macheras P. Biopharmaceutics classification systems for new molecular entities (BCS-NMEs) and marketed drugs (BCS-MD): theoretical basis and practical examples. Int J Pharm. 2008;361(1-2):70-7.

4. Guideline on the investigation of bioequivalence. European Medicines Agency, Committee for Medicinal Products for Human Use (CHMP). London, England; 2010.

5. WHO Technical Report Series, No. 937. Multisource (generic) pharmaceutical products: guidelines on registration requirements to establish interchangeability. World Health Organization (WHO). Geneva, Switzerland; 2006.

6. Cook J, Addicks W, Wu YH. Application of the biopharmaceutical classification system in clinical drug development-an industrial view. AAPS J. 2008;10(2):306-10.

7. Cheng CL, Yu LX, Lee HL, Yang CY, Lue CS, Chou CH. Biowaiver extension potential to BCS class III high solubility-low permeability drugs: bridging evidence for metformin immediaterelease tablet. EurJ Pharm Sci. 2004;22(4):297-304.

8. Jantratid E, Prakongpan S, Amidon GL, Dressman JB. Feasibility of biowaiver extension to biopharmaceutics classification system class III drug products: cimetidine. Clin Pharmacokinet. 2006;45(4):385-99.

9. Lennemäs H, Abrahamsson B. The use of biopharmaceutic classification of drugs in drug discovery and development: current status and future extension. J Pharm Pharmacol. 2005;57(3):273-85.

10. Blume HH, Schug BS. The biopharmaceutics classification system (BCS): class III drugs - better candidates for BA/BE waiver? Eur J Pharm Sci. 1999;9(2):117-21.

11. Polli JE, Abrahamsson BSI, Yu LX, Amidon GL, Baldoni JM, Cook JA, et al. Summary workshop report: bioequivalence, biopharmaceutics classification system, and beyond. AAPS J. 2008;10(2):373-9.

12. Rege BD, Yu LX, Hussain AS, Polli JE. Effect of common excipients on Caco-2 transport of low-permeability drugs. J Pharm Sci. 2001;90(1 1):1776-86.

13. Basit AW, Newton JM, Short MD, Waddington WA, Ell PJ, Lacey LF. The effect of polyethylene glycol 400 on gastrointestinal transit: implications for the formulation of poorly-water soluble drugs. Pharm Res. 2001;18(8):1146-50.

14. Ashiru DAI, Patel R, Basit AW. Polyethylene glycol 400 enhances the bioavailability of a BCS class III drug (ranitidine) in male subjects but not females. Pharm Res. 2008;25(10):2327-33. 
15. Ashiru-Oredope DAI, Patel N, Forbes B, Patel R, Basit AW. The effect of polyoxyethylene polymers on the transport of ranitidine in Caco-2 cell monolayers. Int J Pharm. 201 1;409(102):164-8.

16. Aungst BJ. Intestinal permeation enhancers. J Pharm Sci. 2000;89(4):429-42.

17. Hidalgo IJ, Raub TJ, Borchardt RT. Characterization of the human colon carcinoma cell line (Caco-2) as a model system for intestinal epithelial permeability. Gastroenterology. 1989;96(3):736-49.

18. Artursson P. Epithelial transport of drugs in cell culture. I: a model for studying the passive diffusion of drugs over intestinal absorbtive (Caco-2) cells. J Pharm Sci. 1990;79(6):476-82.

19. Artursson P, Karlsson J. Correlation between oral drug absorption in humans and apparent drug permeability coefficients in human intestinal epithelial (Caco-2) cells. Biochem Biophys Res Commun. 1991;175(3):880-5.

20. Pade V, Stavchansky S. Link between drug absorption solubility and permeability measurements in Caco-2 cells. J Pharm Sci. 1998;87(12):1604-7.

21. Yang Y, Faustino PJ, Volpe DA, Ellison CD, Lyon RC, Yu LX. Biopharmaceutics classification of selected $\beta$-blockers: solubility and permeability class membership. Mol Pharm. 2007;4(4):608-14.

22. Wu CY, Benet LZ. Predicting drug disposition via application of BCS: transport/absorption/ elimination interplay and development of a biopharmaceutics drug disposition classification system. Pharm Res. 2005;22(1):11-23.

23. Thummel KE, Shen DD, Isoherranen N. Appendix II.Design and optimization of dosage regimens: pharmacokinetic data. In: Brunton LL, Chabner BA, Knollman BC, editors. Goodman \& Gilman's the pharmacological basis of therapeutics. 12th ed. New York: McGraw-Hill; 2011. p. 1891-990.

24. U.S. Dept. of Health and Human Services, U.S. Food and Drug Administration. FDA inactive ingredient database: http://www. accessdata.fda.gov/scripts/cder/iig/index.Cfm.

25. Yamashita S, Tanaka Y, Endoh Y, Taki Y, Sakane T, Nadai T, et al. Analysis of drug permeation across Caco-2 monolayer: implication for predicting in vivo drug absorption. Pharm Res. 1997;14(4):486-91.

26. Mason WD, Winer N, Kochak G, Cohen I, Bell R. Kinetics and absolute bioavailability of atenolol. Clin Pharmacol Ther. 1979;25(4):408-15.

27. Schäfer-Korting $\mathrm{M}$, Bach $\mathrm{N}$, Knauf $\mathrm{H}$, Mutschler E. Pharmacokinetics of nadolol in healthy subjects. Eur J Clin Pharmacol. 1984;26(1):125-7.
28. Laskin OL. Clinical pharmacokinetics of acyclovir. Clin Pharmacokinet. 1983;8(3):187-201.

29. Jacobson MA, De Miranda P, Cederberg DM, Burnette T, Cobb E, Brodie HR, et al. Human pharmacokinetics and tolerance of oral ganciclovir. Antimicrob Agents Chemother. 1987;31(8):1251-4.

30. Sharma P, Varma MVS, Chawla HPS, Panchagnula R. In situ and in vivo efficacy of peroral absorption enhancers in rats and correlation to in vitro mechanistic studies. Farmaco. 2005;60(11-12):87483.

31. Tomita M, Sawada T, Ogawa T, Ouchi H, Hayashi M, Awazu S. Differences in the enhancing effects of sodium caprate on colonic and jejunal drug absorption. Pharm Res. 1992;9(5):648-53.

32. Cano-Cebrian MJ, Zornoza T, Granero L, Polache A. Intestinal absorption enhancement via the paracellular route by fatty acids, chitosans and others: a target for drug delivery. Curr Drug Deliv. 2005;2(1):9-22

33. García-Arieta A. Interactions between active pharmaceutical ingredients and excipients affecting bioavailability: impact on bioequivalence. Eur J Pharm Sci. 2014;65:89-97.

34. Becker C, Dressman JB, Amidon GL, Junginger HE, Kopp S, Midha KK, et al. International pharmaceutical federation, groupe BCS. Biowaiver monographs for immediate release solid oral dosage forms: isoniazid. J Pharm Sci. 2007;96(3):522-31.

35. Becker C, Dressman JB, Amidon GL, Junginger HE, Kopp S, Midha KK, et al. Biowaiver monographs for immediate release solid oral dosage forms: pyrazinamide. J Pharm Sci. 2008;97(9): 3709-20.

36. Becker C, Dressman JB, Amidon GL, Junginger HE, Kopp S, Midha KK, et al. Biowaiver monographs for immediate release solid oral dosage forms: ethambutol dihydrochloride. J Pharm Sci. 2008;97(4):1350-60.

37. Jantratid E, Prakongpan S, Dressman JB, Amidon GL, Junginger HE, Midha KK, et al. Biowaiver monographs for immediate release solid oral dosage forms: cimetidine. J Pharm Sci. 2006;95(5):974 84.

38. Kalantzi L, Reppas C, Dressman JB, Amidon GL, Junginger HE, Midha KK, et al. Biowaiver monographs for immediate release solid oral dosage forms: acetaminophen (paracetamol). J Pharm Sci. 2006;95(1):4-14.

39. Dahan A, Miller JM, Amidon GL. Prediction of solubility and permeability class membership: provisional BCS classification of the world's top oral drugs. AAPS J. 2009;11(4):740-6. 